\title{
MISTAKE AS A GROUND FOR NULLIFICATION OF CONTRACTS \\ (THEORIES AND APPROACHES \\ ON ITS RELEVANCE)
}

\author{
Angel Shopov ${ }^{1}$
}

\section{Law Faculty of Plovdiv University "Paisii Hilendarski”, Bulgaria email: a_shopov@uni-plovdiv.bg}

SHOPOV, Angel. Mistake as a Ground for Nullification of Contracts (Theories and Approaches on its Relevance). International and Comparative Law Review, 2013, Vol. 13., No. 1, pp. 61-72. DOI: 10.1515/iclr-2016-0058.

\begin{abstract}
The paper offers the analysis of the theoretical approaches to the problem of mistake in the law of contracts and its relevance for the nullification of the contracts. Author focuses on the several understandings of mistakes: mistake of delusion, mistake of combination of misbelief and misconception, mistake in social interactions etc. Further he evaluates the legal consequences and the practical application of the abovementioned theoretical concepts. Finally author analysis the draft projects related to the mistakes in the law of contacts and their legislative implementation.
\end{abstract}

Keywords: civil law, law of contracts, mistake, theories, legislative proposals

\section{Civil Law Theories on Mistake as a Ground for Nullification of Contracts}

\section{Theories on Mistake as a Fact in interiore hominis}

They are known as theories on error as a psychic fact or as subjective theories. These theories on mistake are well represented in continental legal doctrine's explanation of that ground for invalidation of contracts. We may distinguish two directions among them:

1 Angel Shopov, $\mathrm{PhD}$ is a Chief Assistant Professor in Civil Law at Law Faculty of Plovdiv University “Paisii Hilendarski”, Bulgaria. E-mail: a_shopov@uni-plovdiv.bg. This paper has been translated within the project "Free Exchange of Goods - Legal and Economic Issues", financed by the Scientific Research Fund at Plovdiv University (contract No NI13 UF11). 


\subsection{Theory on Mistake as a Simple Delusion ${ }^{2}$}

\subsubsection{Nature and Characteristics}

According to it, mistake is a discrepancy between any subjective state of mind and objective reality. For example, Pothier perceived mistake as subjective misconception as true of something wrong ${ }^{3}$. Later on, other prominent lawyers (Savigny, Pugliatti and Carnelutti) have defined it in a similar way. They describe the mistake as a case in which there is a false impression of reality ${ }^{4}$.

The theory of mistake, as a simple delusion, has many supporters in Bulgaria. Under our old Law of Obligations and Contracts $(\mathrm{LOC})^{5}$ mistake has been defined as the erroneous notion that we have on something ${ }^{6}$. At the same time, another author gives such a definition. He understood mistake as a discrepancy between reality and subjective perceptions of it $^{7}$.

This theory is widely spread in modern continental civil law doctrine. Famous French lawyers define mistake as consideration of something false as true and vice versa - as consideration of something correct as a falsehood ${ }^{8}$. The first part of that definition is largely influenced by the above mentioned Pothier's notion of mistake. German civil law theoreticians have defined the same phenomenon as "a false understanding of the actual situation", similarly to considerations of Savigny, Pugliati and Carnelutti.

A large number of contemporary writers in Italian and Bulgarian doctrine also share the theory of mistake as a simple delusion. The reason for putting them together in a group is the similarity of their two features. Firstly, I have found continuity between these contemporary views and the foregoing opinions on mistake. It can be observed in several key points - they both support the idea that delusion represents an essential element of mistake; in addition, contempo-

2 Delusion designates a particular state of mind in which there is misconception about reality so Vasilev, L. Grazhdansko pravo na NRB. Obshta chast. 3 prerab. i dop. izd., S., 2000, p. 320. Further on, I will utilize both terms (delusion and misconception) with equal meaning.

3 L'erreur "consiste à prendre pour vrai ce qui est faux" - q.v. Rieg, A. Le rôle de la volonté dans lacte juridique en droit civil français et allemand. Paris. 1961, p. 92.

4 Q.v. Pietrobon, V. Errore, volontà e affidamento nel negozio giuridico. Padova. 1990, p. 321, n. 22.

5 Published in Darzhaven vestnik, No 268, 1892, abrogated by our new LOC, Darzhaven vestnik, No 275, 1950. The latter LOC has entered in force at 1011951 (see $\$ 4$ of its Transition Rules).

6 See Mevorah, N., Lidzhi, D., Farhi, L. Komentar na ZZD. Chl. chl. 1-333. S. 1924, p. 33. The definition is seriously influenced by the understanding of French scientist René Demogue who defines mistake as a psychological state of mind which is incompatible with the objective truth - cf. Ibid.

7 See Dikov, L. Kurs po Grazhdansko pravo. Obligatsionno pravo. Obshta chast. T. III, S., 1934, p. 243.

8 "L’erreur consiste à croire vrai ce qui est faux, ou faux ce qui est vrai" - see Ghestin, J. Traité de droit civil. La formation du contrat. 3e édition. P. 1993, p. 455.

9 See Staudinger / Dilcher, $\$ 119$ para 1; Larenz / Wolf, AT 664 - q.v. in: Mistake, Fraud and Duties to Inform in European Contract Law, ed. by R. Sefton - Green, Cambridge, 2005, p. 101. 
rary views do not hesitate to borrow from the previously mentioned definitions of mistake. The second feature of similarity consists of introducing of additional remarks on field of misconception by some Bulgarian and Italian authors sharing that theory of mistake. I will briefly describe their views.

A group of Italian authors includes in the perimeter of misconception not only false but also distorted representations of reality ${ }^{10}$. Compared with the definition of mistake given by Pothier, their argumentation seems to extend the field of mistake as a ground of nullification of contracts. But, on the contrary, we should have in mind that the latter formula is influenced by local case law. It includes a distorted view of reality in the field of misconception not to broaden the mistake's field of application but to show different reasons (spontaneous or induced by others ${ }^{11}$ ) causing that ground of nullification of contracts.

As I have already mentioned, many Bulgarian authors also accept the theory of error as a psychic fact ${ }^{12}$. A view expressed in our doctrine deserves special attention. It highlights two hypotheses of misconception. ${ }^{13}$ The first is the case where there is a difference between specific individual state of mind and reality. I could confirm that first hypothesis harmonizes perfectly with the views of analyzed theoretical direction. According to the second hypothesis, delusion encompasses situations where there are certain subjective representations on something which in reality completely lacks.

It seems to me that the formula I have just described sticks pretty closer to the concept, advocated by both Italian and Bulgarian author ${ }^{14}$. It also outlines two hypotheses of misconception. The first, quoted above several times, could be called a classical situation of that theory of mistake - in that case the error lies in false representations of the subject revealing his will. Another hypothesis, however, includes in the scope of delusion the ignorance on circumstances that are important for the formation of the inner will of errans ${ }^{15}$.

10 These are professors Roppo, Bianca, Galgano and others. - q.v. by Rossello, C. L'errore nel contratto. Il Codice civile commentato. Artt. 1427 - 1433. Milano. 2004, p. 5, 6 and n. 6.

11 Ibid. Therefrom, we can easily identify main common features between mistake and deceit as grounds for nullification of contracts. The latter is a qualified case of mistake caused by intentional misleading acts (generally belonging) to contract partner of errans. The latter Latin term denominates mistaken contract party.

12 Mistake has been considered as a false impression of reality by Tadzher, V. Grazhdansko pravo na NRB. Obshta chast. Dyal II, S., 1973, p. 271; Gerdzhikov O. Konfiskatsiyata pri nedeystvitelnite sdelki. S. 1988, p. 59; Pavlova, M. Grazhdansko pravo. Obshta chast. 2 prerab. i dop. izd., S., 2002, p. 553, Stefanov, G. Grazhdansko pravo. Obshta chast. Yuridicheski litca, sdelki, predstavitelstvo, pogasitelna davnost. S. 1995, p. 145; cf. Rachev, F. Grazhdansko pravo. S., 2003, p 412. Our case law has also adopted this assumption - see our Supreme court's decision No 38-1974-OSGK (found in: Sadebna praktika. Grazhdanski dela. Obligatsionno pravo. Sastavitel Yavor Mihaylov. T. 6. S. 1999, pp. 353-355), in a decision of International arbitration court of Bulgarian Chamber of Commerce MAD-29-2004 AS BTPP.

13 Tadzher, V. Ibid.

14 Trabucchi, A. Istituzioni di Diritto civile. 40ma ed. Padova, 2001, p. 158; Pavlova, M. Ibid.

15 If ignorance can (not) be included as a component of mistake in formation of will is a problem 
Is there any difference between these two second hypotheses of mistake? When: a) some object is completely missing in reality but the errans has formed certain subjective representation on its existence, on the one hand, and: b) the ignorance of errans, on the other? I think the answer is yes, because ignorance is tantamount to lack of any conception of reality, while in the other case there were some subjective perceptions formed, even though they differ from the objective reality.

\subsubsection{Meaning of Theory of Mistake as a Simple Delusion}

Analyzing the Pothier's thesis - the main supportive element of that theory of mistake - French researchers Ripert and Boulanger have stressed out on its general character. According to them, that concept of mistake can be applied to any intellectual activities ${ }^{16}$ without distinguishing whether or not they have any legal consequences. Ripert and Boulanger's opinion should be shared. Moreover, it also fits to more actual definitions of mistake belonging to that theoretical direction. However, its importance should not be overlooked. And it is still widely spread in civilian doctrine. Secondly, the theory of mistake as a simple misconception has given a strong basis for further justification of the nature of that ground for invalidation of contracts.

\subsection{Theory of Mistake as a Combination of Misbelief and Misconception (In Brief: Theory of Mistake as a Combination)}

\subsubsection{Nature and Characteristics}

This theory is a further development of the previous assumption, describing mistake as a psychic fact. Theory of mistake as a combination adds a second component to the requirement of inadequate subjective perceptions on specific object of knowledge. This is the confidence of errans that his false beliefs match reality. According to this theory, delusion is not sufficient to justify the invalidation of a specific contract on the ground of mistake. In order to apply that reason for nullification, there must be another component of mistake to exist - the confidence that false misconception reflects reality. The errans as its owner should believe in its truth, i.e. he has to be confident that his representations correspond to the referred object. ${ }^{17}$

I have already mentioned the "confidence" and "belief" in the truth of delusion. They both indicate the same component of mistake - the misbelief of mis-

that could be a subject of another detailed analysis.

16 See Rieg, A. Ibid.

17 See Ganev, V. op. cit., pp. 322, 323; Vasilev, L. Ibid; Lapoyade Dechamps, Chr. Droit des obligations. Paris, 1998, p. 61, cf. Vivien, G. De l'erreur determinante et substantielle, Revue trimestrielle de droit civil, 1992, No 2, p. 309; Carnevali, U. I vizi del consenso. - In: Lineamenti di Diritto privato. A cura di Mario Bessone. Terza edizione. Torino, 2002, p. 447. 
guided person. According to that theory of mistake, the combination of these two factors (misbelief and delusion) builds seeming knowledge in the mind of errans. Their simultaneous coexistence causes him entering into a specific agreement under mistake.

The misbelief must be distinguished from another state of mind - the doubt. An individual could have doubt whether specific individual representations match reality. While the first is a positive fact, the same cannot be definitely said for the latter. The state of doubt is equivalent to hesitation that personal impressions differ from reality. This guesswork eliminates the misbelief that ideas and reality match. Therefore, suspicion of a particular person excludes his conviction that individual perceptions correspond to reality. Moreover - that doubt creates a probability that person could later realize he was wrong $)^{18}$.

Hereinafter I should analyze some theses belonging to that theoretical direction. They attract my additional interest because of the ambiguity they contain. An opinion describes mistake as a discrepancy between subjective belief and reality ${ }^{19}$. Its author does not point out the delusion as a separate component of that ground for nullification. Another statement sounds somewhat similar to the previous one, as it does not insist on the simultaneous coexistence of misbelief and misconception. However, in contrast with the former opinion, the latter considers interchangeable two elements of mistake and deems their alternative appearance as a sufficient requirement of that ground for invalidation ${ }^{20}$.

If these views would be analyzed from the viewpoint of the theory of mistake as a combination, they should be described as inaccurate. To justify the existence of mistake, the conviction must be connected with certain misconceptions. Research for conviction of errans would make sense, if in this case his delusion could be found as well. In addition, the misbelief that individual perceptions match reality is different from them. I could prove the latter using the fact that confidence (either belief or misbelief) may exist in the state of mind, notwithstanding that individual impression conforms or not to reality. When we observe only conviction of certain subjective perceptions, they cannot be classified as true or false. We need to examine their contents.

18 See Frosali, Lérrore nella teoria del diritto penale, Roma, 1933, p. 14 - q.v. in Barcellona, P. Profili della teoria dellerrore nel negozio giuridico. Milano. 1962, p. 91, n. 10.

19 See Vivien, G. Ibid.

20 See Stoichev, Kr. Bulgaria: Contracts. International Encyclopaedia of Laws. The Hague. 1999, p. 71. For example, one type of mistake (as a vice of will) is called "misbelief", another is pointed out as "misconception" - cf. Kramer, E.A. Mistake. - In: Kramer, E.A., Probst, Th. IECL, Vol. VII. Contracts in General. Chapter 11. Defects in the Contracting Process. Tübingen. 2001, p. 6. Such an author's style suggests that there is no sharp distinction between two theoretical directions on mistake as a fact in interiore hominis. 


\subsubsection{Meaning of the Theory of Mistake as a Combination}

If the theory of mistake as a combination could be compared with the theory of mistake as a simple misconception, it would be established that the former applies misbelief as a second component of the psychological concept of mistake. An advantage of the theory of mistake as a combination is that most writers apply it in contractual relations. It is for sure that it makes easier the problem on the legal relevance of mistake for invalidation.

\section{Objective Theory of Mistake ${ }^{21}$ (or Theory of Mistake in Terms of Social Interaction)}

\subsection{Nature and Characteristics}

Theories of mistake as a psychic fact have been criticized in Italian literature. In the second half of the twentieth century there has been formulated a different opinion on the nature of mistake as a ground for nullification. In contrast with the subjective theories, that opinion explores mistake not as a fact in interiore hominis. It puts that phenomenon in a more different context.

Objective theory investigates mistake as a fact occurring not only in the individual consciousness, but also puts it in lights of interpersonal communication $^{22}$. That theory appeared consistently with the trends in contract law in the twentieth century. One of them is the focus on social and economic functions of agreements $^{23}$.

The study of the error from this point of view rests on the premise that individuals serve with same tools (language, signs and symbols) - either to interact with each other or to perceive reality ${ }^{24}$. Therefore the objective theory of mistake is influenced by language sciences, mainly by semiotics, which studies the problems of relationship between sign and language; of the meaning of signs in human communication ${ }^{25}$.

21 The name is somewhat arbitrary, since its adherents do not escape entirely from mistake's subjective roots. They also use psychological arguments defining that vice of will. More precisely, this theory would be called "objectified". Here, however, I prefer the name "objective" for the sake of brevity.

22 See Barcellona, P. Op. cit., p. 88-91, and authors cited therein; Rossello, C. Ibid. Probably the same opinion had influenced on a statement expressed "obiter dicta" about mistake in our literature by Kozhuharov, Al. Obligatsionno pravo. Obshto uchenie za obligatsionnoto otnoshenie. Kn. I. S. 1992, s. 89.

23 See Mehren, A., J. Gordley. Op. cit., p. 866.

24 See Barcellona, P. Op. cit., p. 89.

25 Legal science also explores language a) as a kind of legal system with its own semantic rules; and b) the importance of the sign as its element - see Tashev, R. Teoria na talkuvaneto. S. 2001, pp. $74,76,178-181$. 
Objective theory sets up as a major problem the way of determination if there is a mistake. Its followers ${ }^{26}$ argue for the need of a predetermined criterion for assessment. That criterion is external to subjective consciousness. Some adherents call it "a scale of compliance" (termine di riferimento) ${ }^{27}$. Thus the concept of mistake has been "exported" outside the realm of certain individual psychic activity $^{28}$.

The scale of compliance is a product of interaction among people by linguistic means ${ }^{29}$. It consists of common sense of linguistic resources that have been used. Further on, that common sense has been created by social convention ${ }^{30}$. Bulgarian literature calls it the conventional or customary sense of used words and phrases ${ }^{31}$.

Under the objective theory ${ }^{32}$ the occurrence of mistake depends on establishment of meaning, introduced by probable errans in linguistic means as a tool for reflection of reality. It has to be checked out if that meaning coincides or differs from the common sense, established for the same linguistic means. The mistake could be detected when the meaning of linguistic means, used by errans, is different from its conventional sense $\mathrm{e}^{33}$ on condition that the same object of reality has to be described. If we do not make such a comparison between personal sense and conventional sense of linguistic means, signs and symbols, we could not establish whether there is a divergence between an individual state of mind and objects of reality ${ }^{34}$. This divergence should be established by taking into account the expressed will of the alleged errans, his behavior, and other facts having material being. All these circumstances have to occur not later than the conclusion of contract ${ }^{35}$. In other words, material facts which have appeared by a certain moment in time, serve as a kind of objective limitation on the means of determination of mistake ${ }^{36}$.

26 See Barcellona, P. Op. cit., p. 88-91, and authors cited therein; Rossello, C. op. cit., p. 6.

27 See Barcellona, P. Ibid.

28 See Barcellona, P. Op. cit., p. 88; Rossello, C. Ibid. The idea to objectify, but formulated in research for a unifying moment between grounds for invalidation of agreements, expresses Majello, U. La patologia discreta del contratto annullabile. Rivista di diritto civile, 2003, No 4, p. 348 to 352.

29 See Barcellona, P. Op. cit., p. 90, cf. Rossello, C. Ibid.

30 See Barcellona, P. Ibid; cf. Rossello, C. Ibid; Kozhuharov, Al. Ibid; Tashev, R. op. cit., pp. 72, 74, 178-180;

31 Cf. Tashev, R. op. cit., pp. 72, 76, 179, cf. also the provisions of the Art. 9, para. 1 of Bulgarian Law on Normative Acts (LNA) and the Art. 36, para. 1 and Art. 37, para. 1 and 2 of Bulgarian Decree for Application of LNA.

32 See Barcellona, P. op. cit., p. 89, 90; Rossello, C. ibid.

33 So Kozhuharov, Al. Ibid, note 99.

34 See Barcellona, P. op. cit., p. 89, 93.

35 See Barcellona, P. Op. cit., p. 91, Kozhuharov, Al. Loc. cit., p. 89.

36 Cf. This can be deduced from the postulate, which in Bulgarian doctrine has been formulated on the problem of interpretation of transactions: If the addressee understands a declaration of will in accordance with the conventional sense of used words and phrases, the author of the same declaration can not refer to another artificial sense, existed only in his mind, of used words and 


\subsection{Importance of the Objective Theory on Mistake. Relationships with Other Legal Institutions}

Proponents of objective theory have cited it as a continuation of the idea of priority of the declaration over the will, both conceived as components of the legal construction on declaration of will (Willenserklaerung) ${ }^{37}$. However, it is not easy to conclude if this is the leading position in Bulgarian legal doctrine ${ }^{38}$. There are some other opinions known on the issue. One of them gives priority of the will to the declaration, but adds significant objective corrections ${ }^{39}$. It stays closer to the thesis, which examines the will and its declaration in their entirety ${ }^{40}$.

Supporters of this theory point out its two manifestations in Italian legislation $^{41}$. These arguments however, cannot be found in Bulgarian legislation.

All that I have already mentioned creates doubt about the perception of the objective theory of mistake by Bulgarian doctrine and case law. A strong negative answer to that question, however, would be outward. It is worth observing that the problems of common sense have also been discussed by Bulgarian doctrine in a more general level - that of interpretation of legal acts. It turns out that these problems also need to reflect on the legal essays on mistake as a vice of consent.

Finally, I have already highlighted proximity between the objective opinion on mistake and other sciences as semiotics, psychology, etc. The last came to support the following conclusion. Despite the denial of subjective theories on mistake, the objective theory can not entirely avoid the psychological arguments

phrases - see Vasilev, L. Grazhdansko pravo na NRB. Obshta chast, S., 1956, p. 409; Pavlova, M.

Op. cit., pp. $495,496$.

37 Rossello, C. Op. cit., p. 7.

38 In my country the adherents of that priority are Tadzher, V. op. cit., pp. 195, 232; Pavlova, op. cit., pp. 450, 451; Kalaydzhiev, A. Obligatsionno pravo. Obshta chast. IV prerab. i dop. izd. S. 2007, p. 100. Cf. Kozhuharov, Al. Loc. cit., pp. 89-91.

39 So Tashev, R. op. cit., pp. 104-107.

40 See Ganev, V. op. cit., pp. 172, 173; Vasilev, L. op. cit., pp. 385-386; Rieg, A. Op. cit., p. 9-11, 89-91; Ghestin, J. Op. cit., p. 346 to 348. In addition, last two researchers consider that dispute (on priority of the declaration or of the will) out of date.

41 Rossello, C. Ibid. The first manifestation lies in the elimination of the distinction between the effects caused by mistake-vice of consent (errore-vizio) and mistake-obstacle (errore-ostacolo) for consent. Article 1433 of Codice civile italiano (CCI) provides avoidance for both of them, contrary to concepts adopted by French and Italian old literature. These concepts discern mistake-vice of consent from mistake-obstacle. According to their view, the former is a factor leading to nullification; the latter directly causes nullity of agreements. Bulgarian doctrine and case law is not aware of these two types of mistake. The second manifestation of objective theory is suggested by provisions of CCI on basic kinds of relevant mistake. Since they affect the object of the false state of mind, CCI eliminates further researches for subjective components of that state of mind - see Rossello, C. Op. cit., p. 7, 8. In my country, however, LOC is quite frugal from such provisions. (Its key provision is Art. 28, para. 1, which explicitly deals with 2 types of mistake only - mistake to the object and mistake to the person. That paragraph is similar to the art. 1110 of Code civil français, strongly influenced by ideas of Pothier). Naturally, prevailing Bulgarian doctrinal view on the relevant mistake states that the law is not exhaustive on the subject. 
to justify the error as a ground for invalidation of agreements. Objective theory does not leave completely out the subjective perspective on mistake but provides greater clarity on the issue of its interpretation.

\subsection{On the Suitability of Reviewed Theoretical Directions. Conclusion}

Uncertainties or ambiguities on various concepts of mistake can be avoided if we borrow different aspects of represented theoretical directions.

So I would lay the theory of mistake as a combination in the foundation of the legal concept of mistake as a vice of will. That fact will provide continuity with the older notion of mistake as a simple delusion. Further on, the findings of objective theory shall not be ignored. They will be considered as interpretative principles to establish whether there is error-vice. In this way, a twofold effect could be achieved - borrowing foundations of mistake from subjective theories and respecting some conclusions of objective theory on mistake.

Problems that have just been considered are an appropriate starting point for debate on the legal relevance of that ground for annulment.

\section{Approaches to Relevant Mistake: Setting of Common Legal Require- ments or Specific Types of Relevant Mistake? ${ }^{42}$}

\section{Comparative Data}

It was already denoted that the determination of common legal requirements of mistake is a very difficult question, although scientific pursuits had been approached to it for centuries ${ }^{43}$. In national continental legal systems, it is a task mainly performed by the doctrine, based on current (often inadequate) legislation and case $\mathrm{law}^{44}$. To illustrate, I will briefly mention various common legal requirements of mistake.

For example, according to the opinion of the French doctrine any relevant mistake ${ }^{45}$ has to: a) have caused this agreement; b) be excusable and c) affect quality, which the parties expressly or impliedly agreed for.

In Italian literature one of attempts to draw legal prerequisites recognized the mistake as relevant when it: a) affects one of essential elements of the contract

42 Both approaches have been caught by Zezekalo, A. Sdelki, sovershennye pod vliyaniem zabluzhdenia, v proekte kontseptsii sovershenstvovania obshtih polozheniy Grazhdanskogo kodeksa Rossiyskoy federatsii, available from http://www.koteh.ru/journal-yurist/9893.html

43 Initial merit for sketching of legal requirements of (ir-)relevant error belongs to the school of Natural law. Its leaders also refused the casuistic examination of various types of errors - see Zimmermann, R. Op. cit., p 612.

44 Cf. Mistake, Fraud and Duties to Inform in European Contract Law, ed. by R. Sefton - Green, Cambridge, 2005, p 127.

45 See Ghestin, J. Traité ..., p. 518. 
(denoted as its objective core) and b) determines the agreement ${ }^{46}$. This attempt was disputed by numerous theoreticians for different reasons. Maybe the most important of them is that this set of facts is far from normative requirements for the relevance of error ${ }^{47}$. Under Art. 1428 of CCI to justify the invalidation of agreement, mistake must be substantial and identifiable by the other contract party.

The legal requirements on operative error elaborated by Spanish case law ${ }^{48}$ are closer to those concepts. They comprise of two components. Firstly, mistake must relate to the essential content of a specific contract. Thus it leads to conclusion of the latter. Secondly, the error has to be excusable. As we see, the first component of the Spanish construction comprises of two elements identified by previous attempts to establish common legal requirements on relevant mistake.

According to $₫ 871$ of the Austrian Civil Code ${ }^{49}$ the error is legally relevant only if it refers to the principal object or an essential attribute of it to which the intention was principally and expressly directed. In addition, the errans has to prove one of three alternatives: a) that the other party caused the mistake or b) the error must have been obvious to the other party in all the circumstances, or c) that mistake was notified to the other party in good time.

Let us look at the soft law sources of law. Article 3.2.1. of Principles of International Commercial Contracts (PICC - version 2010) denotes mistake as erroneous assumption relating to facts or to law existing when the contract was concluded. The following provision of the Principles entitles the mistaken party to avoid the contract only if at the moment when the agreement was concluded, the mistake was of such importance that a reasonable person in the same situation as the party in error would only have concluded the contract on materially different terms or would have not concluded it at all if the true state of affairs had been known, and a) the other party made the same mistake, or caused the mistake, or knew or ought to have known of the mistake and it was contrary to reasonable commercial standards of fair dealing to leave the mistaken party in error, or b) the other party has not reasonably acted, in reliance on the contract, at the time of avoidance;

The approach of the Principles of European Contract Law and of the Draft of Common Frame of Reference does not differ to that of PICC. As the latter Principles, their provisions indicate that errors in fact and in law are legally relevant - see Art. 4:103 PECL and Art. II-7: 201 DCFR $^{50}$.

46 See Allara, La teoria generale del contratto, p. 182 - q.v. Rosello, C. op. cit., p. 61; Sacco, R. op. cit., p. 386, and other authors cited therein.

47 See Rosello, C. Ibid; Sacco, R. Ibid.

48 Cf. Mistake, Fraud and ..., p. 125.

49 Q.v. Zweigert, K. and Kötz, H. An Introduction to Comparative Law. Third Ed. Oxford, 1998, p. $414,415$.

50 Under Art. 4:103 PECL, para. 1, a party may avoid a contract for mistake of fact or law existing 
It should be recognized that in the doctrine we could find another approach. It consists of casuistic analyzes of different kinds of error and appreciation whether they are either legally relevant or irrelevant ${ }^{51}$. That approach follows tradition of Roman lawyers ${ }^{52}$. They refrained from summarizing constituent elements of operative mistake.

\section{Approach of Bulgarian Law}

Let us now see what the situation in Bulgarian law is. Doctrine prefers the first of the two approaches already outlined. The difficulty comes from the problem that the stated legal requirements for relevant mistake have different scopes. I find it hard to go in details of main author's views on the problem. However, I could only illustrate my impression with the following example. For decades, the main textbooks in civil law were two. Based on the same legal provision (art. $28 \mathrm{LOC}$ ), one of them pointed out two, and the other - three elements, for the relevance of mistake for avoidance of contracts ${ }^{53}$.

Having in mind this problem, on the one hand, and the need to summarize legal requirements for relevant mistake under the prevailing views in our theo$\mathrm{ry}^{54}$, on the other hand, it can be concluded that the mistake in Bulgarian law is relevant for avoidance of contract if:

a) Its components (delusion and misbelief) relate to constituent elements of contracts

and

b) It caused the conclusion of a specific agreement.

when the contract was concluded if: (a) (i) the mistake was caused by information given by the other party; or (ii) the other party knew or ought to have known of the mistake and it was contrary to good faith and fair dealing to leave the mistaken party in error; or (iii) the other party made the same mistake, and (b) the other party knew or ought to have known that the mistaken party, had it known the truth, would not have entered the contract or would have done so only on fundamentally different terms. The provision of Art. II-7: 201 DCFR has similar content. Ii differs from Art. 4:103 PECL by adding fourth hypothesis to the established three alternatives of behaviour of the partner of errans - when the mistaken party's partner caused the contract to be concluded in mistake by failing to comply with a pre-contractual information duty or a duty to make available a means of correcting input errors.

51 So for example Witz, Cl. Droit privé allemand. 1. Actes juridiques, droits subjectifs: BGB, Partie générale. Loi sur les conditions générales d’affaires. Paris. 1992, pp. 264 - 281.

52 Cf. D. 18, 1, 9; D. 18, 1, 11, 1; D. 18, 1, 14 and D. 18, 1, 41, 1; Zimmermann, R. The Law of Obligations. Roman Foundations of the Civilian Tradition. New York, 1996, p. 587-596; Andreev, M. Rimsko chastno pravo. S., 1993, pp. 293, 294; Schermaier, M. J. Mistake, misrepresentation and precontractual duties to inform: the civil law tradition - In: Mistake, Fraud and Duties to Inform in European Contract Law, ed. by R. Sefton - Green, Cambridge, 2005, pp. 40 - 42.

53 See respectively Vasilev, L. op. cit., pp. 321-322 and Tadzher, C. op. cit., p. 271. The same is the impression if we look at legal requirements of mistake in foreign literature already outlined.

54 See Ganev, V. Uchebnik po obshta teoria na pravoto. T. I., S. 1990, pp. 322, 323, 326, 327; Vasilev, L. Grazhdansko pravo... S., 2000, p. 320; Tadzher, V. Op. cit., p 271; Stoichev, Kr. Bulgaria: Contracts. International Encyclopaedia of Laws. The Hague. 1999, p. 71, Pavlova, M. Op. cit, pp. 553-554. 
If we make a brief comparison between these legal requirements and those, outlined by foreign doctrine, of course we will find some differences. Which are the most obvious? Bulgarian law does not involve additional criteria for a relevant error. For instance, it does not require a mistake to be identifiable or excusable.

In the meantime, by striving to summarize the features of the relevant error, our doctrine continues to keep Romanistic tradition of analysis of mistake. Along with the description of its legal requirements, Bulgarian theory explores main kinds of mistake and studies their legal significance ${ }^{55}$.

In conclusion, it should be recognized that the second approach itself is not enough to appreciate the legal relevance of a certain type of mistake. Therefore, it depends on the achievements of the first approach. If we want to consider the legal relevance of any described type of error, it has to be put through the prism of legal prerequisites for that vice of will.

55 See textbooks in our civil law, except for Rachev, F. op. cit., p. 412. The latter follows a completely casuistic approach. 